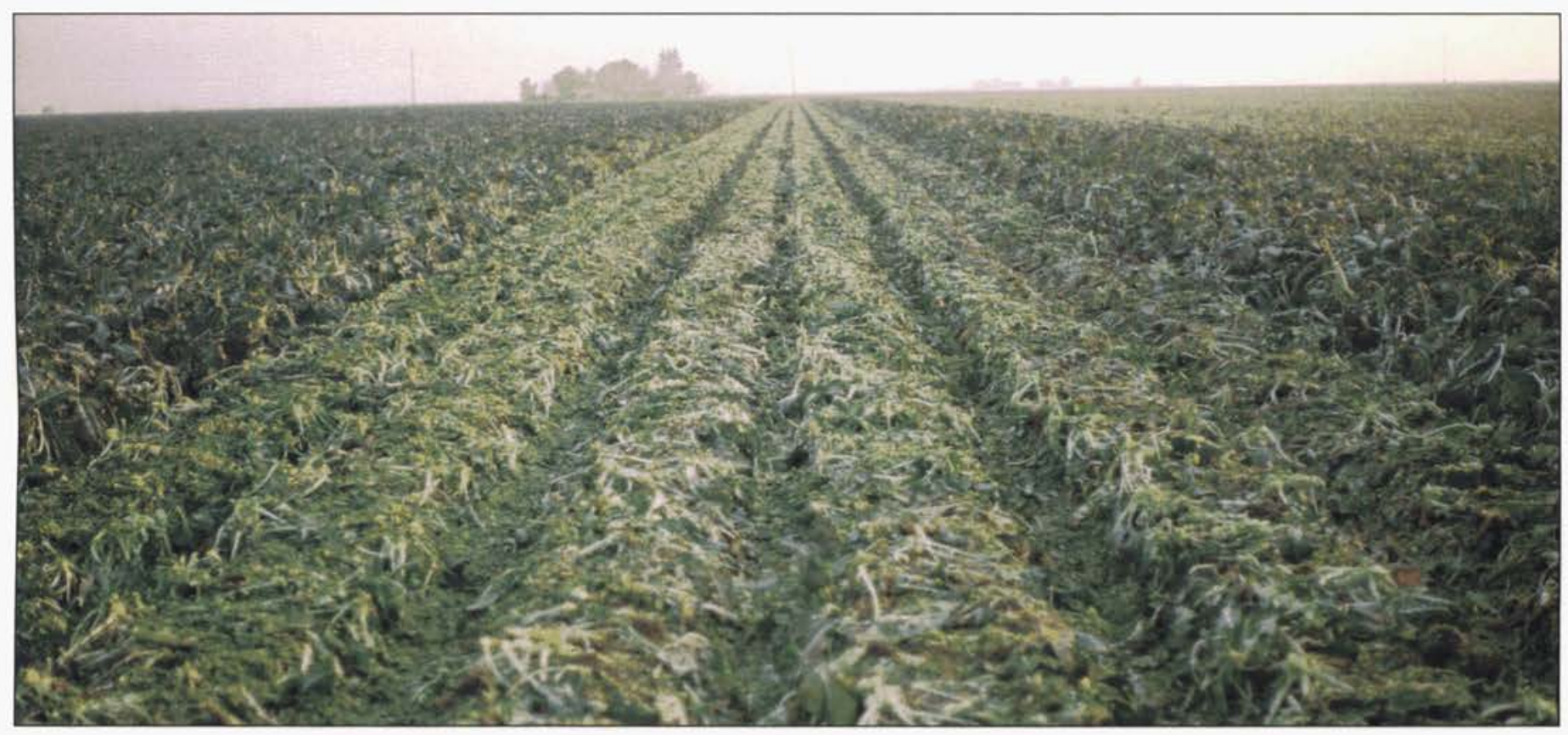

Broccoli field harvested, chopped and ready to be disked near Huron.

\title{
Organic matter recycling varies with crops grown
}

\author{
Jeffrey Mitchell \\ a Tim Hartz \\ Stu Pettygrove \\ a Daniel Munk \\ a Donald May \\ Frank Menezes u John Diener a Tim O'Neill
}

\begin{abstract}
Central San Joaquin Valley farmers have been working with researchers and consultants to evaluate soil and crop management practices, enhance biologically integrated pest management and facilitate information exchange through the West Side Biologically Integrated Farming Systems (BIFS) Project. As part of this project, the amounts and composition of aboveground biomass in postharvest residues of typical rotational crops of the region were surveyed from 1996 to 1998. Crop residue biomass ranged from 9,560 pounds per acre for corn following grain harvest to $\mathbf{5 7 0}$ pounds per acre for onions. A very large range of organic matter recycling thus results from the various intensive cropping strategies that are currently used in this region.
\end{abstract}

The West Side of the San Joaquin Valley is one of the most productive agricultural regions of the world. The leading crops of this region include processing tomatoes, cotton, onions, garlic, cantaloupes and lettuce, which have been grown on more than 570,000 acres annually in recent years in western Fresno County alone. West Side farmers produce more than onethird of Fresno County's annual \$3 billion agricultural output and help make it the largest-producing county in the United States.

During the last 30 years, land-use patterns on the West Side have changed considerably. In 1965, over $60 \%$ of the acreage in this area was typically planted to wheat, barley and safflower. In the early 1990s, these crops were grown on only about $10 \%$ of the area (table 1). Higher-value crops, including a number of vegetables and cotton, are now common in West Side rotations. It has been as- sumed that this increase in the production of these higher-value crops has led to less organic matter returned to the soil, more aggressive tillage and a possible decline in soil quality. Crop rotations in the West Side region are very dynamic and typically reflect a number of current as well as anticipated economic and agronomic considerations. Decisions concerning what crops to grow on a given field are generally made annually and are based primarily on anticipated revenue as well as on the need to rotate crops to minimize the build up of soil pathogens.

In the fall 1995, the West Side Biologically Integrated Farming Systems (BIFS) Project was initiated with the objectives of monitoring and evaluating on-farm demonstrations of soil and crop management practices designed to maintain soil quality; investigating opportunities for enhancing biologically integrated pest manage- 
TABLE 1. Fresno County crop production, 1965-1994

\begin{tabular}{|c|c|c|c|c|}
\hline Year & Safflower, barley and wheat & Cotton & Other field crops & Vegetable crops \\
\hline 1965 & 352 & 186 & 304 & 41 \\
\hline 1970 & 325 & 167 & 343 & 52 \\
\hline 1975 & 338 & 247 & 253 & 122 \\
\hline 1980 & 219 & 451 & 186 & 94 \\
\hline 1985 & 132 & 421 & 305 & 155 \\
\hline 1990 & 52 & 359 & 217 & 230 \\
\hline 1994 & 53 & 350 & 213 & 230 \\
\hline
\end{tabular}

Source: Fresno County Department of Agriculture. Agricultural Crop and Livestock Reports

TABLE 2. Common crop rotations of the West Side San Joaquin Valley between Five Points and Huron, based on 1996 BIFS Project farmer survey

\begin{tabular}{lllllll}
\hline \hline & Year 1 & Year 2 & Year 3 & Year 4 & Year 5 & Year 6 \\
\hline Class I soils* & Melon & Garlic & Cotton & Tomato & Melon & Cotton \\
& Lettuce/lettuce & Tomato & Cotton & Onion & Lettuce/lettuce & Tomato \\
& Melon & Lettuce/lettuce & Onion & Tomato & Cotton & Tomato \\
& Broccoli & Tomato & Melon & Garlic & Tomato & Cotton \\
& Cotton & Tomato & Onion & Cotton & Tomato & Cotton \\
& Cotton & Tomato & Cotton & Tomato & Cotton & Tomato \\
& Cotton & Wheat & Sugarbeet & Cotton & Wheat & Cotton \\
& & & & & &
\end{tabular}

"Land Capability Classification. USDA Natural Resources Conservation Service. Class I soils have few or no limitations and are suitable for cultivated crops. Class IIIw6 soils may permit cultivation of a narrower range of crops due to drainage and salinity conditions.

ment in the region; and facilitating information exchange among West Side farmers, consultants and researchers.

At the beginning of the project, participating farmers indicated that they were concerned about maintaining soil organic matter levels and were increasingly considering additions of compost, manure and cover crops to their rotations.

Soil organic matter is associated with many important processes in soils, including water infiltration, cation storage and nutrient cycling via microbial activity, and is generally considered to favorably affect soil tilth. Current soil organic matter levels in agricultural soils of farms in the West Side BIFS Project typically average $0.83 \%$.

A 1996 survey of these farmer participants revealed a wide variety of rotation patterns that are typically followed throughout the West Side (table 2 ). To provide information on organic matter that is typically returned to the soil following harvest in West Side rotations, we surveyed the amounts and composition of aboveground biomass in postharvest residues of typical rota- tional crops of the region from 1996 to 1998 .

\section{Sample collection}

We collected aboveground postharvest crop residues from either 10.5 $\mathrm{ft}^{2}$ or $105 \mathrm{ft}^{2}$ quadrats, depending on the general distribution uniformity of residues throughout fields in the West Side region between Five Points and Huron immediately following harvest. In general, at least four samples were collected in each sampled field (table 3 ) The residues were dried in a forcedair oven at about $140^{\circ} \mathrm{F}\left(60^{\circ} \mathrm{C}\right)$ and weighed prior to being ground in a Wiley mill. We then determined tissue nitrogen $(\mathrm{N})$, carbon $(\mathrm{C})$, phosphorus $(\mathrm{P})$ and potassium $(\mathrm{K})$ using standard analytical procedures at the DANR Analytical Laboratory at UC Davis.

\section{Residue amounts and composition}

Crop residue biomass ranged from 9,560 pounds (lb) per acre for corn following grain harvest to $570 \mathrm{lb}$ per acre for onions (table 3 ). Broccoli, cotton, wheat following grain harvest and safflower residue levels were intermedi- ate at $6,546,5,220,4,830$ and $4,040 \mathrm{lb}$ per acre, respectively. Vegetable crop residues generally were most variable due to the lower harvest efficiencies of these crops and the fact that market conditions dictate the harvest intensity of these high-value crops. The relatively high variability of residue amounts of a machine-harvested crop such as processing tomato may result from differences in crop maturity at the time of harvest (because of contracted delivery deadlines), which may mean that large amounts of green fruit are left in some fields, particularly for late-season crops. For most tomato fields, however, green fruit seldom make up more than $10 \%$ of the total fruit on harvested plants.

Removing different components of a crop at harvest can also affect the quantity of residues (table 3 ). Following the harvest of grain, for example, wheat residues averaged about 4,810 $\mathrm{lb}$ per acre, whereas after removing a wheat crop as green chop in bales, the resulting residue was only $670 \mathrm{lb}$ per acre. Residues for field crops such as corn, wheat and barley in California are slightly higher than residues for these crops grown in other parts of the United States. For example, aboveground corn residues average $7,570 \mathrm{lb}$ per acre and wheat residues average $3,160 \mathrm{lb}$ per acre throughout the United States, compared to 9,560 and $4,810 \mathrm{lb}$ per acre, respectively, in our survey.

There are no previous California studies with which to compare the results of our survey. In 1978, Knutson and Miller published DANR Leaflet 21303, Agricultural Residues (Biomass) in California: Factors Affecting Utilization. The aim of this work, however, was to estimate the amount of agricultural residues that might be converted to products such as animal feed, particle board and energy. The data used in this early study were generally based on estimates of postharvest residue amounts as proportions of total expected crop biomass production, and were not derived from actual field sampling.

Using data collected from our field surveys, we estimated the amount of crop residue biomass returned to the 
TABLE 3. Postharvest crop residue biomass returned to the soil and elemental composition of residues from San Joaquin Valley, 1996-98

\begin{tabular}{|c|c|c|c|c|c|c|c|}
\hline Crop residue & $\begin{array}{l}\text { No. of fields } \\
\text { sampled }\end{array}$ & $\begin{array}{l}\text { Total number } \\
\text { of samples of } \\
\text { crop residue }\end{array}$ & $\begin{array}{l}\text { Residue biomass } \\
\text { (mean } \pm \text { standard } \\
\text { error of the mean) }\end{array}$ & Carbon & Nitrogen & Phosphorus & Potassium \\
\hline & & & Ib/acre & (............... & (.................... & acre ....................... & 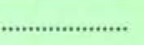 \\
\hline Corn following grain harvest & 1 & 10 & $9,560 \pm 560$ & 3,824 & 57 & 21 & 232 \\
\hline Broccoli & 2 & 8 & $6,546 \pm 1,182$ & 2,271 & 157 & 19.6 & 196 \\
\hline Cotton & 4 & 14 & $5,220 \pm 380$ & 2,156 & 63 & 9.9 & 121 \\
\hline Wheat following grain harvest & 4 & 12 & $4,810 \pm 590$ & 1,680 & 82 & 8.2 & 103 \\
\hline $\begin{array}{l}\text { Sudangrass (short-season } \\
\text { cover crop) }\end{array}$ & 1 & 6 & $4,470 \pm 310$ & & & & \\
\hline Sugarbeet & 1 & 9 & $3,836 \pm 577$ & 1,373 & 42 & 12 & 96 \\
\hline Safflower & 3 & 7 & $2,690 \pm 195$ & & & & \\
\hline Tomato & 4 & 16 & $2,880 \pm 400$ & 973 & 52 & 4.3 & 57 \\
\hline Seed lettuce & 1 & 10 & $2,730 \pm 700$ & 1,063 & 41 & 5.5 & 139 \\
\hline Lettuce & 3 & 13 & $1,950 \pm 210$ & & 66 & 5.8 & 111 \\
\hline Barley following green chop & 2 & 7 & $1,100 \pm 50$ & & & & \\
\hline Corn following silage harvest & 3 & 17 & $1,060 \pm 70$ & & & & \\
\hline Garlic & 2 & 9 & $930 \pm 270$ & 371 & 14 & 2.5 & 12 \\
\hline Wheat following baling & 1 & 4 & $670 \pm 70$ & & & & \\
\hline Onion & 2 & 12 & $570 \pm 77$ & & & & \\
\hline
\end{tabular}

TABLE 4. Predicted crop residue biomass returned to the soil in hypothetical 6-year crop rotations

\begin{tabular}{|c|c|c|c|c|c|c|c|}
\hline Region & Year 1 & Year 2 & Year 3 & Year 4 & Year 5 & Year 6 & $\begin{array}{l}\text { Total projected } \\
\text { residue biomass }\end{array}$ \\
\hline & & & & & & & Ibs per acre \\
\hline West Side & Cotton & Tomato & Cotton & Tomato & Cotton & Tomato & 24,303 \\
\hline West Side & Cotton & Tomato & Garlic & Cotton & Tomato & Garlic & 18,058 \\
\hline West Side & Tomato & Garlic & Wheat & Tomato & Onion & Cotton & 13,144 \\
\hline West Side & Lettuce/lettuce & Wheat & Garlic & Tomato & Cotton & Wheat & 14,258 \\
\hline West Side & Tomato & Garlic & Barley & Tomato & Onion & Tomato & 11,238 \\
\hline West Side & $\begin{array}{l}\text { Garlic/sudangrass } \\
\text { cover crop }\end{array}$ & Wheat/broccoli & Corn & Cotton & Tomato & Safflower & 35,876 \\
\hline West Side* & $\begin{array}{l}\text { Tomato/ } \\
\text { cover crop }\end{array}$ & Cotton & Wheat & $\begin{array}{l}\text { Cover crop/ } \\
\text { tomato }\end{array}$ & $\begin{array}{l}\text { Cover crop/ } \\
\text { cotton }\end{array}$ & Cover crop/corn & 44,576 \\
\hline Midwestt & Wheat & Wheat & Wheat & Wheat & Wheat & Wheat & 18,978 \\
\hline Midwest & Corn & Soybean & Corn & Soybean & Corn & Soybean & 27,132 \\
\hline Midwest & Corn & Corn & Corn & Corn & Corn & Corn & 45,444 \\
\hline
\end{tabular}

-Fall/winter cover crops (barley/wheat) estimated at 3,500 lb per acre December-March

†Soil organic matter in temperate agroecosystems

soil in several hypothetical 6-year

West Side crop rotations (table 4). For comparison, three standard rotations from the midwest United States are also indicated using data from the CRC Handbook Soil Organic Matter in Temperate Agroecosystems. In general, these estimates reveal a considerable range of residue amounts being returned to the soil in these rotations over a 6-year cycle. Straight cottontomato-garlic and cotton-tomato rotations return 18,060 and $24,300 \mathrm{lb}$ dry matter per acre, respectively. Rotations with more vegetables tend to have smaller residue returns. Integrating short-season cover crops during the winter when evapotranspiration demand is typically low in the West Side region and selecting high-residue crops can increase estimated residue biomass returns to over $44,000 \mathrm{lb}$ per acre. Additional windows of opportunity for cover cropping may exist following crops that are harvested during early summer or midsummer. For example, traditional winter annual cover crops such as vetch, wheat, barley or various medic and clover species may contribute considerably more biomass to West Side rotations.

The elemental composition of crops surveyed here also varied widely (table 3). Biomass carbon returned to the soil ranged from $3,824 \mathrm{lb}$ per acre for corn following grain harvest to 371 lb per acre for garlic. The mineral composition of crops surveyed here also varied considerably and reflects various factors, including crop maturity at harvest (as in lettuce) and effects of differences in soil available nutrients among fields, particularly with respect to potassium.

These data point to a very large range of organic matter recycling that results from various intensive cropping strategies in this region and may be useful in determining optimal rotation schemes. Although rotation decisions ultimately depend on economic factors, judicious crop rotation may be a means for sustaining soil organic matter, in addition to the deliberate use of amendments such as compost, manure and cover crops. However, the long-term impacts of these amendments on soils in semiarid, irrigated regions such as the San Joaquin Valley are not well characterized. These impacts are the focus of our broader West Side BIFS on-farm monitoring program. The impacts of various till- 
